\title{
BioLink
}

Jurnal Biologi Lingkungan, Industri, Kesehatan

Available online http://ojs.uma.ac.id/index.php/biolink

\section{MACROFUNGI DIVERSITY IN MOUNT BURNI TELONG BENER MERIAH REGENCY ACEH PROVINCE}

\author{
Siti Nurchalidah, Zulfan Arico*, \& Fitriani \\ Biology Study Program, Faculty of Engineering, Universitas Samudra, Indonesia
}

Submited : 09-06-2020; Reviewed : 06-10-2020; Accepted : 27-11-2020

*Corresponding author: E-mail : aricozulfan@unsam.ac.id

\begin{abstract}
Mount Burni Telong has a diversity of fungi that play an important role in the forest ecosystem. This study aimed to determine the types of macrofungi found in Mount Burni Telong and index diversity macrofungi found in Mount Burni Telong. The method used in this study was to use the pathway method by observing macrofungi along the hiking trail with a distance of 10 meters to the left and 10 meters to the right starting from an altitude of $1800 \mathrm{mdpl}$ to an altitude of $2600 \mathrm{mdpl}$. Macroscopic fungi found were to identified and measured the physico-chemical parameters of the environment. Macroscopic fungi found were dominated by the Basidiomycota division and the Polyporaceae family. The results obtained were 31 macroscopic fungi from 2 divisions, 6 classes, 6 orders, 21 families, 26 genera, and 31 species. The most macroscopic fungi found in the Basidiomycota division, Agaricomycetes class, were 23 species and at least in the Ascomycota division, Pezizomycetes class, was as many as 1 species.
\end{abstract}

Keywords: Diversity; Fungi; Burni Telong

How to Cite: Nurchalidah, S., Arico, Z., \& Fitriani. (2021). Macrofungi Diversity in Mount Burni Telong Bener Meriah Regency Aceh Province, BioLink: Jurnal Biologi Lingkungan, Industri dan Kesehatan, Vol.7 (2): Hal. 139-153 


\section{INTRODUCTION}

Mount Burni Telong is one of the active volcanoes in Aceh Province. This mountain is located in the Gayo Highlands, Bener Meriah Regency with a peak altitude of $2624 \mathrm{~m}$ above sea level. Mount Burni Telong last erupted on December 7, 1924 which caused damage to the surrounding vegetation (Putri et al., 2015). Mount Burni Telong has a high diversity of flora and fauna with typical vegetation characteristics of wet highlands, including Edelweiss, nepenthes, pine and coffee (Gemasih et al., 2017). Mount Burni Telong also has a fungi diversity that plays an important role in the forest ecosystem.

Hawksworth \& Robert (2017) stated that the number of species of fungi that have been identified is around 2.2 to 3.8 million species, there is an increasing compared to that in 2001 of 1.5 million species. The highest increasing occurred in 2010 as many as 1,800 species per year due to the use of molecular identification for species restrictions. In Indonesia it is assumed that there are about 12,000 types of fungi (mushrooms), while in the world there are around 47,000 types. Types that have been known are around 28,700 macro fungi and 24,000 rusts, smuts and molds and 13,500 lichens (Mardji \& Massofian, 2009).

Fungi or mushrooms are one of the biotic components that play a role in maintaining balance and preserving nature. In addition, mushrooms contain complex organic compounds such as cellulose, hemi cellulose, pectin, starch, and lignin, which act as decomposers to help the decomposition of organic matter in the forest ecosystem. In this case (Khayati \& Hadi, 2016) reported that ecologically, fungi have a real role in ecological events such as associations with plants that play a role in the nutrient cycle, food webs that affect the survival of tree saplings and tree growth. Anggraini et al., (2015) also reported that fungi help to fertilize the soil by providing nutrients for plants. Fungi also play a role in regulating the nutrient cycle, The nutrient cycle will be hampered if the litter does not decompose properly, so that the fungus becomes a decomposing organism with the help of enzymes found in fungal mycelium (Nasution et al., 2017; Wahyuni et al., 2019). Thus, macroscopic fungal research is very significant to determine the rate of nutrient decomposition and soil fertility.

\section{MATERIALS AND METHODS}

This research was conducted in the area of Mount Burni Telong, Bener Meriah Regency, Aceh Province. Determination of sampling points was carried out using the path method by observing macroscopic fungi along the climbing route with a distance of 10 meters to the right and 10 
meters to the left along the hiking trail (Wahyuni et al., 2019). Mount Burni Telong has an altitude of 2600 masl. This research was conducted on the climbing route of Mount Burni Telong starting from an altitude of 1800 masl to an altitude of 2600 masl (Gemasih, et al., 2017).

The fungi obtained during observation were then measured for environmental physico-chemical parameters in the form of $\mathrm{pH}$ and soil moisture as measured using a soil tester, humidity and air temperature were measured using a hygrometer, and light intensity was measured using a lux meter, measurements were made in the area where each fungus was found. The fungi (mushrooms) specimens found were then documented using a digital camera. The documentation process started from the appearance of the macrohabitat and microhabitat of the fungus, then led to the top of the mushroom cap and the height of the fungus starting from the base to the tip of the mushroom cap. Documentation was carried out by juxtaposing mushrooms with a comparison scale in the form of a measuring instrument, namely a ruler (Wahyuni et al., 2019).

Observation was made on color, pores, volva, rings, hoods, stalks and smell of fungi, habitat/substrate (dead wood, living wood, soil, leaf litter/soil or rocks). Mushroom samples found were photographed based on where they grew. Mushroom samples were taken, namely for soft mushrooms taken with the substrate so that all parts of the mushrooms were taken and not cut, while for mushrooms with a hard texture and sticking to them, taking mushrooms by using a knife could also cut the substrate thinly. The mushroom samples obtained were put in a plastic bag containing $70 \%$ alcohol and labeled hanging (Darwis et al., 2020).

Mushrooms whose morphological characters have been recorded were then identified by referring to the identification book, namely World Biology Encyclopedia of Conifers and Mushrooms (Suhono, 2012) and A guide to Common Fungi of The Hunter Central Rivers Region (Skye and Pam, 2014).

\section{RESULTS AND DISCUSSION}

\section{Types of Macroscopic Fungi on Mount}

\section{Burni Telong}

The results obtained shows that 31 macroscopic fungi from 2 divisions, 6 classes, 6 orders, 21 families, 26 genera, and 31 species can be seen in Table 1 . 
Table 1. Types of Macroscopic Fungi on Mount Burni Telong

\begin{tabular}{|c|c|c|c|c|c|c|}
\hline No. & Division & Class & Ordo & Famiy & Genus & Spesies \\
\hline 1. & Ascomycota & Pezizomycetes & Pezizales & Sarcoscyphaceae & Cookeina & Cookeina sulcipes \\
\hline 2. & Basidiomycota & Agaricomycetes & Agaricales & Agaricaceae & Agaricus & Agaricus parvitigrinus \\
\hline 3. & Basidiomycota & Agaricomycetes & Agaricales & Bolbitiaceae & Conocybe & Conocybe apala \\
\hline 4. & Basidiomycota & Agaricomycetes & Agaricales & Hygrophoraceae & Hygrophorus & Hygrophorus eburneus \\
\hline 5. & Basidiomycota & Agaricomycetes & Agaricales & Hymenogastraceae & Galerina & Galerina clavata \\
\hline 6. & Basidiomycota & Agaricomycetes & Agaricales & Hymenogastraceae & Galerina & Galerina marginata \\
\hline 7. & Basidiomycota & Agaricomycetes & Agaricales & Marasmiaceae & Marasmius & Marasmius calhouniae \\
\hline 8. & Basidiomycota & Agaricomycetes & Agaricales & Marasmiaceae & Marasmius & Marasmius epiphyllus \\
\hline 9. & Basidiomycota & Agaricomycetes & Agaricales & Marasmiaceae & Omphalotus & Omphalotus nidiformis \\
\hline 10. & Basidiomycota & Agaricomycetes & Agaricales & Mycenaceae & Mycena & Mycena cystidiosa \\
\hline 11. & Basidiomycota & Agaricomycetes & Agaricales & Mycenaceae & Panellus & $\begin{array}{l}\text { Panellus stipticus var. } \\
\text { albus }\end{array}$ \\
\hline 12. & Basidiomycota & Agaricomycetes & Agaricales & Nidulariaceae & Nidula & Nidula candica \\
\hline 13. & Basidiomycota & Agaricomycetes & Agaricales & Physalacriaceae & Armillaria & Armillaria mellea \\
\hline 14. & Basidiomycota & Agaricomycetes & Agaricales & Pluteaceae & Pluteus & Pluteus lutescens \\
\hline 15. & Basidiomycota & Agaricomycetes & Agaricales & Psathyrellaceae & Coprinellus & $\begin{array}{l}\text { Coprinellus } \\
\text { disseminatus }\end{array}$ \\
\hline 16. & Basidiomycota & Agaricomycetes & Agaricales & Tremellaceae & Tremella & Tremella fuciformis \\
\hline 17. & Basidiomycota & Agaricomycetes & Boletales & Paxillaceae & Paxillus & Paxillus involutus \\
\hline 18. & Basidiomycota & Agaricomycetes & Boletales & Sclerodermataceae & Scleroderma & Scleroderma citrinum \\
\hline 19. & Basidiomycota & Agaricomycetes & Boletales & Sclerodermataceae & Scleroderma & $\begin{array}{l}\text { Scleroderma } \\
\text { sinnamariense }\end{array}$ \\
\hline 20. & Basidiomycota & Agaricomycetes & Cantharellales & Cantharellaceae & Craterellus & $\begin{array}{l}\text { Craterellus } \\
\text { cornucopioides }\end{array}$ \\
\hline 21. & Basidiomycota & Agaricomycetes & Polyporales & Ganodermataceae & Ganoderma & Ganoderma aplanatum \\
\hline 22. & Basidiomycota & Agaricomycetes & Polyporales & Polyporaceae & Fomes & Fomes annosus \\
\hline 23. & Basidiomycota & Agaricomycetes & Polyporales & Polyporaceae & Gleoporus & Gloeporus sp. \\
\hline 24. & Basidiomycota & Agaricomycetes & Polyporales & Polyporaceae & Hexagonia & Hexagonia tenuis \\
\hline 25. & Basidiomycota & Agaricomyecetes & Polyporales & Polyporaceae & Microporus & Microporus affinis \\
\hline 26. & Basidiomycota & Basidiomycetes & Polyporales & Polyporaceae & Microporus & Microporus sp. \\
\hline 27. & Basidiomycota & Basidiomycetes & Polyporales & Polyporaceae & Microporus & Microporus sp.2 \\
\hline 28. & Basidiomycota & Basidiomycetes & Polyporales & Polyporaceae & Pycnoporus & Pycnoporus coccineus \\
\hline 29. & Basidiomycota & Heterobasidiomycetes & Tremellales & Tremellaceae & Tremella & Tremella fuciformis \\
\hline 30. & Basidiomycota & Homobasidiomycetes & Agaricales & Tricholomataceae & Pleurotus & Pleurotus sp. \\
\hline 31. & Basidiomycota & Tremellomycetes & Tremellales & Exidiaceae & Exidia & Exidia alba \\
\hline
\end{tabular}


The most common macroscopic fungi found in the Basidiomycota division, Agaricomycetes class, were 23 species and the least was in the Ascomycota division, Pezizomycetes class, as many as 1 species (Table 1). In this case Santoso (2004) explained that the macroscopic fungal species were most often found from the basidiomycota division. The characteristic of the basidiomycota division is macroscopic, while the members of the ascomycota division are microscopic and only a small part is macroscopic or have fruiting body.

\section{Macroscopic Fungus Description}

The characteristics of macroscopic fungi that were found on Mount Burni Telong are as follows.

\section{Agaricus parvitigrinus}

Habitat : dead wood twigs

\section{Description}

Mushrooms Agaricus parvitigrinus has a convex hood shaped, smooth surface with fine striped edges. The middle hood is black with white edges. It has dark gray lamellae from the stalk of the fruiting body, initially light pink, then grayish brown. The shape of the stalk of the fruiting body is the same from the base to the tip, the location of the eccentric fruit stalk, the surface of the stalk is smooth, and grayish in color. The habitat of this fungus is on soil and dead wood twigs, solitary life and this fungus was found in Pintu Rimba and Shelter 2.

\section{Marasmius epiphyllus}

Habitat : rotten leaves

\section{Description}

Mushrooms Marasmius epiphyllus has a convex hood shaped, smooth hood surface with ribbed hood edges. White Lamella with regular type of lamella. Fruit stalk is slender and thin, brittle, white-yellow on top and yellow-brown towards the base, and the type of location of the central stalk. This mushroom has a height of $2 \mathrm{~cm}$ (Marasmio,2017). This fungus grows on dead leaves, precisely on the nerves of the leaves in groups and was found in Pintu Rimba and Shelter 2.

\section{Marasmius calhouniae}

Habitat : weathered logs

Description

Mushrooms Marasmius calhouniae has a convex hood shaped, white, the surface of the hood is translucent when moist with the edges of the hood raised, and has very thin flesh. Regular type of lamella with white lamellae edges. The stalk of the fruiting body is brittle, hollow, tapered at the base, smooth surface, white at the top and graybrown to light brown at the base, and the type of location is the central stalk. This mushroom has a height of $0.3 \mathrm{~mm}$ (Marasmio,2017). Marasmius calhouniae 
mushroom grows on dead tree branches in groups and was found in the Jungle Door.

\section{Scleroderma sinnamariense}

Habitat : weathered logs

Description

Mushrooms Scleroderma sinnamariense has a round shaped and grows on the ground. Scleroderma sinnamariense has a yellow color with irregular white warts. This fungus does not have a stalk, only rhizoid or mycelium which attaches directly to the ground. When this fungus breaks, it releases grayish spores (Lee, 2012). This fungus grows solitary on the forest floor and was found in Shelter 1.

\section{Mycena cystidiosa}

Habitat : leaf litter

Description

Mushrooms Mycena cystidiosahas a white convex papilla hood shaped with a brown center. It has a smooth hood surface covered with smooth fibrils with notched hood edges. The height is $6.5 \mathrm{~cm}$. Regular lamellae with white lamellae margins and become brownish with age towards the stem. The stalk of the fruiting body is initially brown and pale towards the hood, slender in the shape of a slindric, has a smooth surface, and the type of location of the stalk is central (Skye \& Pam, 2014). This fungus grows in the leaf litter in groups and was found in Shelter 1.

\section{Fomes annosus}

Habitat : weathered logs Description

Mushrooms Fomes annosus has no stalk, hard woody texture of the fruiting body, and brown with white on the edge of the fruiting body. Slightly convex and flat, the edges of the fruiting body are thin, and white. The underside of the fruiting body is white, and the lamellae is porous (Tampubolon, 2010). This fungus grows on rotten logs in groups and was found in Shelter 1.

\section{Craterellus cornucopiodes}

Habitat : land

\section{Description}

Mushrooms Craterellus cornucopiodes has the shape of a hood like a funnel that extends at the top. The top and inner surfaces are black or dark gray while the outer surfaces are light gray with a nonsmooth surface. The stalk of the fruiting body in this fungus is eccentric and the edges are smooth with the fruit stalk is the same size from base to tip (Tri et.al, 2016). This mushroom has a height of $2 \mathrm{~cm}$, grows solitary on the ground and was found in Shelter 1.

\section{Galerina clavata}

Habitat : land

Description 
Mushrooms Galerina clavata has a convex hood shaped and there is a thin umbo in the middle so that the hood is broad convex, orange and brown in the center, and over the edge of the hood is pale yellow. Smooth hood surface with pointed hood edges. Regular type of lamella, brown, lamella adnate attachment, and subdistant spacing lamellae with brown lamellae edges. The stalk of the fruiting body is the same size from base to tip, has a smooth warty surface, and brownish yellow (Jordan, 2004). This mushroom has a height of $2 \mathrm{~cm}$, grows solitary on the ground and was found in Shelter 1.

\section{Hygrophorus eburneus}

Habitat : weathered logs

Description

Mushrooms Hygrophorus eburneus has a white convex hood shape, with a smooth hood surface and straight striped hood edges. Mushrooms have a height of $0.8 \mathrm{~cm}$. Types of lamellae are branch to the edge, slightly curved upward, and shaped like an arc. In case the spacing is far enough, that space can be seen between the short lamellae (lamellulae). The stalk of the fruiting body has the same width along the fruiting body and is hollow. It is slightly tapered downwards, white, and the upper part of the fruiting body is covered with short white fibrils and the type of location of the eccentric stalk (Fang et.al, 2009). It grows solely on weathered logs and was found in Shelter 1.

\section{Coprinellus disseminatus}

Habitat : weathered logs

Description

Mushrooms Coprinellus disseminates has a beige-brown hood and parabolic shape, smooth hood surface with pointed hood edges. This mushroom has a height of 3.3 $\mathrm{cm}$. Lamella is gray brown, when adults turn brownish black. The stalk of the fruiting body is creamy-brown, shiny, cylindrical, slender and hollow, and the type of location of the stalk is central and smooth (Skye \& Pam, 2014). It grows on rotten logs in groups and was found in Shelter 1 and Shelter 2.

\section{Hexagonia tenuis}

Habitat : weathered logs

\section{Description}

Mushrooms Hexagonia tenuis has no stalk, the texture of the fruiting body is hard woody, there are concentric zones of brown with lighter colored edges when actively growing. Semicircular, smooth surface with slightly wavy edges. The lower part of the fruiting body is light brown (Skye \& Pam, 2014). It grows solely on weathered logs and was found in Shelter 1.

\section{Pycnoporus coccineus}

Habitat : weathered logs 
Description

Mushroom Pycnoporus coccineus its fruiting body is fan-shaped, has a hard texture, and is yellow to reddish yellow. The type of reed / pore lamellae is seen from the outside such holes. Life sticks to the substrate. The habitat of the Pycnoporus coccineus fungus is mostly found in weathered wood and lives in groups (Rahma et. Al., 2018). This mushroom has a height of $1.5 \mathrm{~cm}$ and was found in Shelter 1 .

\section{Gloeporus sp.}

Habitat: tree roots

Description: mushrooms Gloeporus sp has a hood that resembles a fan, dark brown, a bit thick and hard, while the outside is white and wavy. Regular lamella is brownish in color. The stalk is sessil attached to the dead wood (Frescha, 2017). This fungus grows on dead wood solitary and was found in Shelter 2.

\section{Microporus sp.}

Habitat : weathered logs

Description

Mushrooms Microporussp. has a woody texture and resembles a fan. Shiny hood is light brown, there are concentric zones of dark brown. Smooth surface with wavy edges. The underside of the fruiting body is white and the lamellae is porous. The stalk is lateral, and sticks to deadwood (Frescha, 2017). This fungus has a height of $3.5 \mathrm{~cm}$, grows solitary on weathered logs and is found in Shelter 2.

\section{Microporus sp. 2}

Habitat : weathered logs

Description

Mushrooms Microporus sp.2 has a woody hard fruiting body texture, the hood is colorful, and alternating dark brown with slightly curved yellowish edges. Shaped like a fan, with a smooth hood surface. The underside of the fruiting body is white with porous lamellae. The stalk is lateral and sticks to the dead wood (Frescha, 2017).

This fungus has a height of $6 \mathrm{~cm}$, grows on rotten logs solitary and was found in Shelter 2.

\section{Pluteus lutescens}

Habitat : weathered logs

Description

Mushrooms Pluteus lutescens has a lime yellow hood, a convex hood shape with a fine grain surface of the hood. White lamellae closely spaced. The stalk of the fruiting body is yellow, the shape of the base is rounded, with a striped surface. Has a height of $4 \mathrm{~cm}$ (Skye \& Pam, 2014). It grows solely on weathered logs and was found in Shelter 2.

\section{Exidia alba}

Habitat: weathered logs

Description 
Mushrooms Exidia alba has a gelatinous fruiting body, an upper surface containing spores and a sterile lower surface. Smooth surface and fruiting body grow in groups (Skye \& Pam, 2014). This fungus grows on weathered stems in groups and was found in Shelter 2.

\section{Polyporus sp.}

Habitat : weathered logs

Description

Mushrooms Polyporus sp. has a fanshaped fruiting body, has a chewy fruiting body texture, light brown with dark brown edges. The upper surface is smooth and slippery while the bottom is smooth and wrinkled. The type of lamellae is crossed and white (Skye \& Pam, 2014). It grows on rotten logs in groups and is found in Shelter 2.

\section{Ganoderma aplanatum}

Habitat : weathered logs

Description: mushrooms

Ganoderma

aplanatum is a wood rot fungus. This mushroom has a semicircular fruiting body with a fruiting body size of $10 \mathrm{~cm}$ in diameter, hard and stiff texture with a thickness of $1.5 \mathrm{~cm}$, and on the upper side it has a radial line with a reddish brown color on the fruiting body and the lower side has a hymenophore in the form of pores small pores. It does not have a fruit stalk, so it is directly attached to the substrate and lives solitary by sticking to the dead trees (Elis et al., 2016). This mushroom was found in Shelter 2.

\section{Tremella fuciformis}

Habitat : weathered logs

Description

Mushrooms Tremella fuciformis has a hood shaped like a leaf blade that separates from the stem with a length of 3-4 centimeters. This mushroom is yellowish white with curly tufted edges. The fruiting body is directly attached to the damp log, and without the stem. This fungus is a soft fungus, the surface is not slippery but also not rough, but rather gummy because it contains substances like jelly (Solle et al., 2017). MushroomTremella fuciformis has a height of $4 \mathrm{~cm}$, grows in rotten banana stalks in groups and was found in Shelter 2.

\section{Panellus stipticusvar. albus}

Habitat : weathered logs

Description

Mushrooms Panellus stipticusvar. albus has a parabolic hood shaped, is white, smooth surface with toothed edges with small round teeth, and curves slightly inward. The lamella type is regular with white edges, closely spaced, and often branched. The stalk of the fruiting body is the same size from the base to the tip of the smooth surface and the type of location of the stalk is eccentric (Roody, 2003). This 
fungus has a height of $2.2 \mathrm{~cm}$, grows in banana stems that have rotted solitary and was found in Shelter 2 .

\section{Conocybe apala}

Habitat : rotten banana stalks

Description

Mushrooms Conocybe apala has a light pink hood, is conical shaped with a pointed hood edge, and has a smooth hood surface. It has height of $3.4 \mathrm{~cm}$. Creamy lamella with regular type of lamella, and cream colored edges of lamella. The stalk of the fruiting body is light-colored, cylindrical, has a smooth, hollow and brittle surface with a slightly swollen base, and the type of location of the stalk is central (Skye \& Pam, 2014). The fungus grows solely on weathered logs and was found in Shelter 2.

\section{Pleurotus sp.}

Habitat : rotten banana stalks

Description

Mushrooms Pleurotus sp. has a sideways (lateral) stalk, white color and a rounded base. The hood of the mushroom has a white color with a slippery surface and slightly grooved edges (Trubus, 2007). This mushroom has a height of $2 \mathrm{~cm}$, lives in groups in rotten banana leaves, and was found in Shelter 2.

\section{Omphalotus nidiformis}

Habitat: weathered logs
Description

Mushrooms Omphalotus nidiformis has a deep fan-shaped hood, smooth surface with inward rolled edges. Omphalotus nidiformis has a cream-colored hood with a brown edges. Lamella is creamy and decurrent and often dripping with and has a smooth edge. The stalk of the fruiting body is tapered to the base, the type of the stalk is lateral. This mushroom has a height of $2.4 \mathrm{~cm}$ and its thin flesh is generally creamy white. This fungus lives on rotting logs in groups and was found in Shelter 2.

\section{Cookeina sulcipes}

Habitat : weathered logs

\section{Description}

Mushrooms Cookeina sulcipes belongs to the fungal cup group, which can be identified by the shape of the sporocarp like a bowl, has a stalk, and spores are produced on the inside of the smooth bowl. Cookeina sulcipes are red in color and have hair and thin lines (Weinstein, et.al, 2002). This fungus grows solitary on weathered logs and is found in Shelter 2.

\section{Microporus affinis}

Habitat : weathered logs

Description

Mushrooms Microporus affinis has a fruiting body in a lateral position such as a fan, a pale white hood with brownish red stripes, a smooth, unlined edge $2-4 \mathrm{~cm}$ in 
diameter, and a smooth smooth upper surface that has a stalk located on the edge of the hood or eccentric (Elis et al., 2016). This fungus grows on weathered branches in groups and was found in Shelter 2 .

\section{Scleroderma citrinum}

Habitat : land

Description

Mushrooms Scleroderma citrinum known as the earth ball mushroom because it is round and grows on the ground. Scleroderms citrinum has a round fruiting body with a hard and scaly surface, yellow with irregular brown warts. This fungus does not have a stalk, only rhizoid or mycelium which attaches directly to the ground. When this fungus breaks, it will produce a dark gray ash (Skye \& Pam, 2014). This fungus grows solitary on the ground and was found in Shelter 2.

\section{Nidula candica}

Habitat: weathered logs

Description

Mushrooms Candida nidula is often called bird's nest fungus, because of the very small cup-shaped fruiting body between 3-8 mm in diameter, 5-15 mm high which looks like a small bird's nest covered with thin skin and on the outside there are fine feathers. When the cover peels off, it looks like eggs which are small collections (peridioles) of compressed spores (Desjardin et.al, 2015).
This fungus grows on dead tree branches in groups and was found in Shelter 2 .

\section{Galerina marginata}

Habitat : weathered logs

Description

Mushrooms Galerina marginata has a parabolic hood shape, is orange-brown color, and has a grain-coated hood surface with smooth edges without lines. The type of lamella is regular, attached to the stem, and closely spaced yellowish at first and turns brown as the spores mature. The fruiting body stalk is lateral type, the surface of the stalk is mottled with whitish fibrils, and the shape of the stalk is the same size from base to tip and is brownish yellow (Kuo, 2016). This fungus has a height of 3.4 $\mathrm{cm}$, grows solitary on weathered logs and was found in Shelter 2.

\section{Paxillus involutus}

Habitat : land

Description

Mushrooms Paxillus involutushas a convex hood shape, when it is old the hood begins to flatten and form a funnel, and the surface of the hood is smooth. Lamela is brown and gets browner with age, fusing to the stalk of the mushroom fruiting body. Mushroom fruit stalk has a smooth surface and is cylindrical in shape, yellowish brown with an eccentric stalk type (Mazza, 2008). This mushroom has a height of $4 \mathrm{~cm}$, grows 
solitary on the ground, and was found in Shelter 3.

\section{Armillaria mellea}

Habitat: weathered logs

Description

The fungus Armillaria mellea has a convex hood at first but then flattens eventually with the central umbo raised, then becoming plate-shaped. Has golden yellow color and fades to yellowish or brownish, there are small brown scales lying in the center arranged radially. Smooth hood surface with curved hood edges. White lamellae initially changes color to brownish yellow with age, the lamellae is attached to the stem. The stalk of the fruiting body is the same at the top, but tapers to the base due to the clustered growth pattern, light brown color, and smooth surface (Kuo, be seen in Table 2 .

Table 2. Conditions and physical and chemical factors of the hiking trail environment

\begin{tabular}{lccccc}
\hline \multicolumn{1}{c}{ Location } & soil pH & Soil moisture (\%) & $\begin{array}{c}\text { Air } \\
\text { temperature } \\
(\mathbf{C})\end{array}$ & Humidity (\%) & $\begin{array}{c}\text { Light intensity } \\
\text { (candela) }\end{array}$ \\
\hline $\begin{array}{l}\text { The jungle } \\
\text { door }\end{array}$ & 6 & 30 & 19 & 90 & 226 \\
Shelter 1 & 6 & 30 & 19 & 90 & 467 \\
Shelter 2 & 6 & 30 & 19 & 90 & 301 \\
Shelter 3 & 5.3 & 40 & 18 & 89 & 1812 \\
\hline
\end{tabular}

The macroscopic fungi that grew on Mount Burni Telong had physical environmental factors that supported the area. The physical and environmental factors measured in the Mount Burni Telong area were different, it could be seen from the various types of macroscopic fungi found in the Mount Burni Telong area.

\section{Location Characteristics}

At each post of the hiking trail had a different vegetation character. From the ranger post to the jungle door there were coffee plantations along the path to the jungle door. At Shelter 1, there were shrubs and trees that can be found. Shelter 2 was a very humid area, there were lots of mushrooms and trees with a high canopy density, while shelter 3 had little canopy cover, low tree density, and a lot of light intensity so that there were few mushrooms. The physical-chemical conditions of the environment were measured with one measurement and can 
(2006), most macroscopic fungi were intensity is low. According to Achmad mesophilic, grew at moderate (2011) light with low light intensity will temperatures of $10-40{ }^{\circ} \mathrm{C}$, and the affect the growth of fungi for the formation optimum temperature was $25-35{ }^{\circ} \mathrm{C}$. of fruiting bodies, spores or the release of Mushrooms can live at $70-90 \%$ humidity spores for fungi that were positive (Khayati \& Hadi, 2016). Mushrooms phototropism. While the canopy density activity at a pH below 7.0. According to was low, the incoming light intensity was Deacon (2006), mushrooms can grow in a high. If the incoming light was high $\mathrm{pH}$ range of 4.8-8.0 and the optimum $\mathrm{pH}$ is intensity it will inhibit the growth of the 5.5-7.5. The density of the crown cover structure of the reproductive tools and would affect the incoming light. If the fungal spores.

canopy density was high, the incoming light
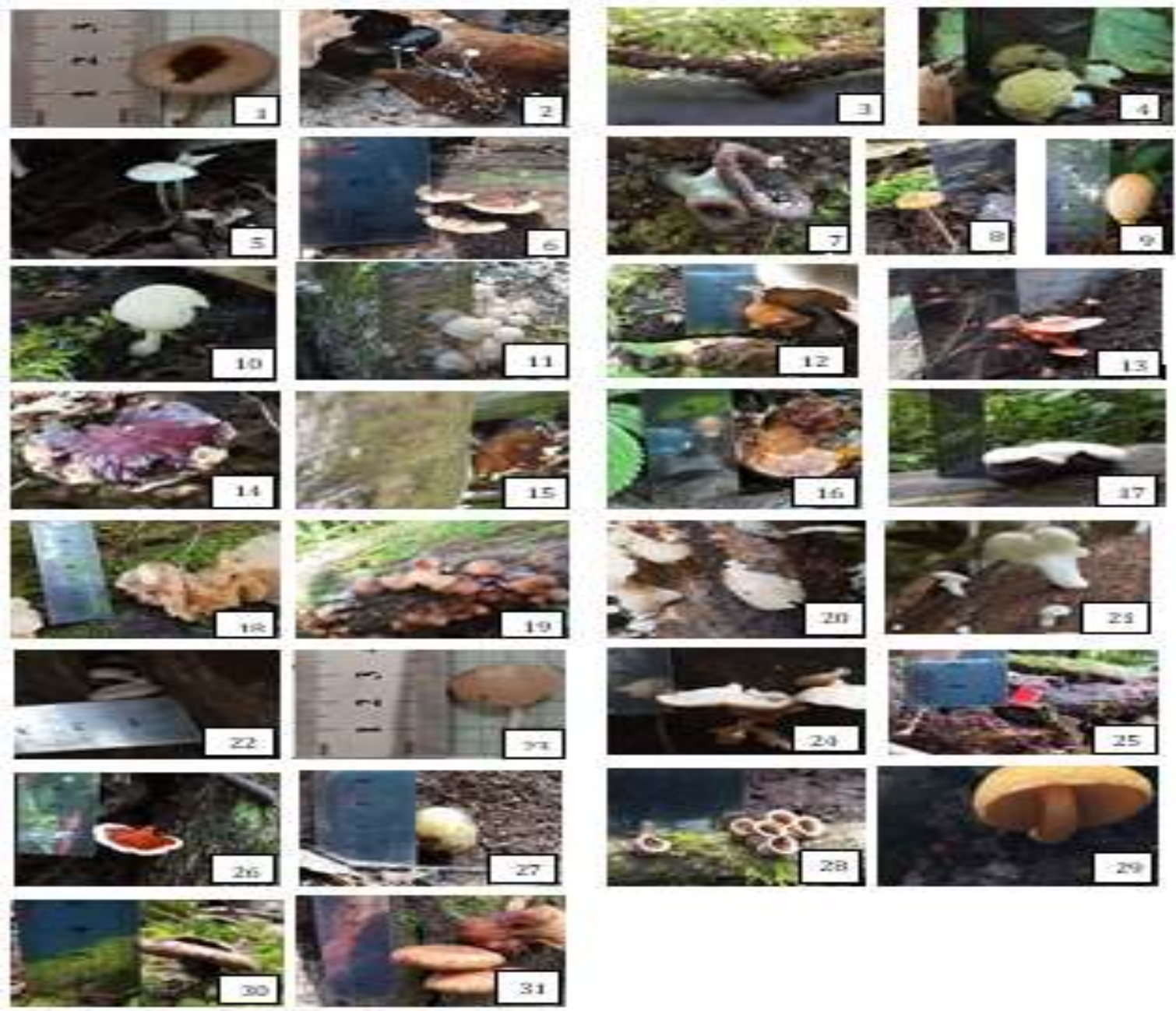

Picture 1. 1. Agaricus parvitigrinus; 2. Marasmius epiphyllus; 3. Marasmius calhouniae; 4. Scleroderma sinnamariense, 5. Mycena cystidiosa; 6. Fomes annosus; 7. Craterellus cornucopoides; 8. Galerina clavata; 9. Pluteus lutescens; 10. Hygrophorus eburneus; 11. Coprinellus disseminatus; 12. Hexagonia tenuis; 13. Pycnoporus coccineus; 14. Gloeporus sp.; 15. Microporus sp.; 16. Microporus sp.2; 17.Ganoderma aplanatum; 18. Exidia alba; 19. Polyporus sp.; 20. Tremella fuciformis; 21. Pleurotus sp.; 22 Panellus stipticus; 23 . Conocybe apala; 24. Omphalotus nidiformis; 25. Cookeina sulcipes; 26. Microporus affinis; 27. Scleroderma citrinum; 28. Nidula candica; 29. Galerina marginata; 30. Paxillus involutus; 31. Armillaria mellea. 


\section{CONCLUSION}

The types of fungi found in Mount

Burni Telong were 31 macroscopic fungal species from 2 divisions, 6 classes, 6 families, 21 orders, 26 genera. Most species of fungi were found from the Polyporaceae family.

\section{REFERENCES}

Achmad. (2011). Panduan Lengkap Jamur. Jakarta: Penerbit Swadaya.

Anggraini, K. Siti, K. \& Masnur, T.(2015). Jenis-Jenis Jamur Makroskopis di Hutan Hujan Mas Desa Kawat Kecamatan Tayan Hilir Kabupaten Sanggau. Jurnal Probioint. 4(3): 6o-64.

Darwis, W. U. Ulandasari. R.H Wibowo. Sipriyadi. \& R.R.S Astuti. 2020. Biodiversitas Fungi makroskopis di Sekitar Kawasan Cagar Alam Tanjung Laksaha Pulau Enggano Bengkulu. Bioedukasi. 11 (1): 18-26.

Deacon, J.W. (2006). Fungal Biology, 4th edition. Oxford: Blackwell Publisihing.

Desjardin, D.E. Wood, M.G. \& Stevens, F.A.(2015). California Mushrooms: The Comprehensive Identification Guide. Portland: Timber Press

Elis, T. Asadi, A \& Nur, A. (2016). Jenis-Jenis Jamur Basidiomycetes Familia Polyporaceae di Hutan Pendidikan Universitas Hasanuddin Bengo-Bengo Kecamatan Cenrana Kabupaten Maros. Jurnal Biologi Makasasar (Bioma). 1(1). 33-38.

Fang, J,P. \& Zhong, Z.C.(2009). Study on Hygrophorus eburnus yak milk beverage. China Dairy Industry (in Chinese). 37 (6): 62-64.

Frescha, M.S. (2017). Keanekaragaman jenis jamur makroskopis di Hutan Geopark Merangin Provinsi Jambi sebagai pengayaan materi ajar mikologi. Thesis. Universitas Jambi.

Gemasih, M. Djufri. \& Supriatno.(2017). Kerapatan edelweis (Anaphalis javanica) di Gunung Burni Telong Bener Meriah. Jurnal Ilmiah Mahasiswa Fakultas Keguruan dan Ilmu Pendidikan Unsyiah. 2(1). 8-14.

Hawksworth, D. \& Robert, L.(2017). Fungal Diversity Revisited: 2.2 to 3.8 Million Species. Microbiol Spectrum. 5(4).
Jordan, M.(2004). Ensiklopedia Jamur Inggris dan Eropa. Frances: Lincoln ltd.

Khayati, L. \& Hadi, W.(2016). Keanekaragaman Jamur Kelas Basidiomycetes di Kawasan Lindung KPHP Sorong Selatan. Prosiding Symbion (Symposium on Biology Education). 1(1). 213-222.

Kuo, M.(2016). Galerina marginata. MushroomExp ert.Com. Diunduh pada tanggal 16 Desember 2019.

Lee, S.(2012). Checklist of Fungi of Malaysia. Malaysia: University Of Malaya.

Nasution, J., Handayani, H., \& Riyanto, R. (2017). Pengaruh Olahan Berbagai Produk Makananterhadap Kadar Protein Padajamur Tiram Putih (Pleurotus ostreatus). EKSAKTA: Jurnal Penelitian dan Pembelajaran MIPA, 1(2).

Marasmio. (2017). Asociacion cultural "Baxauri" Kultur elkartea. Mikologia. Bajauri.

Mardji, D \& Massofian, N.(2009). Keanekaragaman Jenis Jamur Makro di Hutan Lindung Gunung Lumut. Jurnal Kehutanan Tropika Humida. 2(2). 143-155.

Mazza, G. (2008). Paxillus involutus. Monaco Nature Encyclopedia.

Putri, T. Purba, M. \& Razali.(2015). Klasifikasi tanah di Lereng Selatan Gunung Burni Telong Kecamatan Nukit Kabupaten Bener Meriah Provinsi Aceh. Jurnal Online Agroteknologi. 3(1): 264-275.

Rahma, K. Nursalmi, M. \& Muslich, H.(2018). Karakteristik Jamur Makroskopis di Perkebunan Kelapa Sawit Kecamatan Meureubo Aceh Barat. Prosiding Seminar Nasional Biotik 2018. 157-164.

Roody, W.C.(2003). Mushrooms of West Virginia and the Central Appalachians. Lexington. Kentucky: University Press of Kentucky.

Santoso. (2004). Biologi dan Kecapakan Hidup. Bandung: Ganeca Exact.

Skye, M \& Pam.0. (2014). A Guide To Common Fungi Of The Hunter Central Rivers Region. Australia: Hunter Local Land Services.

Solle, H. Ferdinandus, K. \& Simon, T. N.(2017). Keanekaragaman jamur di Cagar Alam Gunung Mutis Kabupaten Timor Tengah Utara, Nusa Tenggara Timur. Biota. 2(3): 105-110.

Tampubolon, S.(2010). Keanekaragaman jamur makroskopis di Hutan Pendidikan Universitas Sumatera Utara Desa Tongkoh 
Kabupaten Karo Sumatera Utara. Skripsi. Universitas Sumatera Utara.

Tri, R. Sri, P. \& Azwin.(2016). Keanekaragaman jamur basidiomycota di Hutan Tropis Daratan Rendah Sumatera Indonesia (studi kasus di Arboretum Fakultas Kehutanan Universitas Lancang Kuning Pekanbaru). Jurnal Kehutanan. 11 (2). 98-111.

Trubus. (2007). Pijakan anyar jamur tiram. Jakarta: Trubus Swadaya

Wahyuni, N. Eka, N. Narendra, N. Yuni, F. Gading, G. Khudrotul, N. Nur, L. Ufairanisa, I., Anindya, N., Fadhila, P. Ni'matuzahroh. Intan, A.(2019). Biodiversitas basidiomycota di Tegal Bunder dan Ambyarsari, Taman Nasional Bali Barat, Bali, Indonesia. Pros Sem Nas Masy Biodiv Indo. 5 (2): 280-285.

Weinstein, R.N. \& P. fister, D.H.(2002). A phylogenetic study of the genus Cookeina. Myxologia. 94 (4): 673-682. 